\title{
Excised Leaf Bioassay: Phenotypic Expression of Natural Resistance in Apple against the Obliquebanded Leafroller
}

\author{
Joseph J. Schwarz, Jay F. Brunner \\ Department of Entomology, Washington State University, Tree Fruit Research and Extension Center, Wenatchee, USA \\ Email: joseph.schwarz@wsu.edu
}

How to cite this paper: Schwarz, J.J. and Brunner, J.F. (2017) Excised Leaf Bioassay: Phenotypic Expression of Natural Resistance in Apple against the Obliquebanded Leafroller. Advances in Entomology, 5, 125.

http://dx.doi.org/10.4236/ae.2017.51001

Received: September 20, 2016

Accepted: December 19, 2016

Published: December 22, 2016

Copyright $\odot 2017$ by authors and Scientific Research Publishing Inc. This work is licensed under the Creative Commons Attribution International License (CC BY 4.0).

http://creativecommons.org/licenses/by/4.0/

\begin{abstract}
Different approaches were assessed in the development of a bioassay method that would provide data necessary to evaluate resistance of apple genotypes to the obliquebanded leafroller (OBLR) Choristoneura rosaceana (Harris). A leaf disc method used to evaluate the impact of pesticides on leafrollers resulted in high levels of leaf-abandonment of first and second instar larvae. Inserting leaf petioles into water soaked Oasis foam resulted in a significant reduction in overall leaf weight and diminished the appearance of leaf quality. When leaf petioles were inserted into waterfilled Eppendorf vials, leaf weight increased and overall leaf quality appeared to be good. We opted to adopt this latter whole-leaf bioassay method, which though very time consuming, provided a robust assessment of OBLR life history parameters against different apple genotypes. Across all apple genotypes evaluated, male larvae developed faster than females to pupation as well as to adulthood, while females developed faster as pupae and were heavier than male pupae. OBLR larvae reared on leaves from different apple genotypes displayed significant variability in development time, pupal weight, larval survivorship, and number of offspring produced. We utilized three indices to characterize host acceptance, sub-lethal effects, and lethal effects of OBLR to apple genotypes. Our results indicated that 'Lady', 'Viking', and 'Northern Spy' show some of the highest levels of resistance against OBLR, while 'Granny Smith' was quite susceptible to OBLR and could be used in future studies identifying apple genotypes with relative resistance to OBLR.
\end{abstract}

\section{Keywords}

Choristoneura rosaceana, Malus, Genotype, Lethal Effects, Sub-Lethal Effects

\section{Introduction}

The obliquebanded leafroller (OBLR), Choristoneura rosaceana (Harris), is a tortricid moth native to and widely distributed in North America [1] [2]. OBLR is polyphagous 
[3] and may cause severe economic losses when left uncontrolled [4] [5] [6]. In apple, OBLR larvae primarily feed on foliage; flower buds in spring and terminal shoot leaves in summer [7] [8] [9]. However, they can cause significant fruit injury [5] and is potentially one of the most destructive lepidopteran pests of apple in Washington, second only to codling moth, Cydia pomonella (L.) [10]. OBLR has two generations per year depending on heat units and quality of food [4] [11]. In the central Washington State apple-growing district, OBLR larvae feed on apple during three distinct periods: spring (overwintered larvae), midsummer (summer generation larvae), and late summer/fall (overwintering larvae).

Broad-spectrum organophosphate insecticides have traditionally provided control of OBLR in both the US and Canada [12] [13]. However, the development of insecticide resistance and cross-resistance in OBLR is widely reported [14]-[22]. Additionally, broad-spectrum insecticides have detrimental effects against natural enemies [23], disrupting biological control of secondary pest aphids and spider mites [24] [25].

Research on natural resistance in apple has been primarily focused on aphids such as the woolly apple aphid (Eriosoma lanigerum Hausm.), the green apple aphid (Aphis pomi De Geer), the rosy apple aphid (Dysaphis plantaginea Pass.), the leaf-curling aphid (Dysaphis cf. devecta Wlk.), and the Russian wheat aphid (Diuraphis noxia Mordvilko) [26]-[31] as well as diseases such as apple scab (Venturia inaequalis Cooke), powdery mildew (Podosphaera leucotricha Ellis and Everh.), and fire blight (Erwinia amylovora Burrill) [29] [32] [33] [34]. Very little research has focused on apple resistance against chewing insect pests. Most early reports of resistance were based on observational studies [35]-[41] of which only two have shown correlations with Malus chemistry [36] or leaf type and phenology [38]. Onstad et al. [42] reported an excised leaf bioassay that displayed leaf-age effects against OBLR. More recent studies have shown that there is natural variation in Malus that could be captured in breeding programs against chewing insect pests like leafroller and codling moth. For example, the putative gene, Cob1, in 'Prima' confers resistance to the brownheaded leafrollers in New Zealand [43]. Sugar metabolites on the surface of apple foliage of 'Golden Delicious' influenced codling moth oviposition in France [44]. Research in Switzerland identified QTLs of 'Discovery' that are associated with codling moth susceptibility [45], which also appear to be a function of fruit quality [46] [47].

The WSU apple-breeding program has focused on the development of varieties that will produce high-quality fruit with minimal horticultural disorders. An additional objective is incorporating resistance to key diseases like fire blight and powdery mildew into new varieties. However, little effort has been made to consider resistance to insect pests. Growing concerns over insecticide resistance and the appearance of new exotic pests, such as the brown marmorated stinkbug, Halyomorph halys Stål [48], indicate that the search for insect resistance traits in Malus is increasingly important.

In this paper we discuss the development of a whole-leaf bioassay method used in measuring resistance in selected apple genotypes against OBLR. The method maintains high-quality leaves while quantifying parameters of host acceptance (anitxenosis) and specific sub-lethal and lethal (antibiosis) effects through all OBLR life stages. 


\section{Materials and Methods}

\subsection{OBLR Colony}

Insects used in this study originated from a laboratory colony of OBLR that was established from larvae collected in apple orchards in Mattawa, WA in 1990. This colony has been reared continuously on a pinto bean diet following the method of Shorey and Hale [49] under constant conditions of temperature $\left(23^{\circ} \mathrm{C} \pm 2^{\circ} \mathrm{C}\right.$ ), relative humidity (RH, $73 \%$ ), and photoperiod (16L: 8D).

\subsection{Apple Genotypes}

Accessions of Malus spp., located at the WSU Sunrise Research Orchard (Rock Island, WA) provided diverse genotypes to evaluate possible resistance to OBLR. The apple genotypes (accession number) used in this study were: 'Antonovka 1.5' (107196), 'PRI 1346-2' (589785), 'Redfree’ (594111), 'Florina' (588747), 'Cox’s Orange Pippin' (588853), 'Northern Spy' (588872), 'Liberty' (588943), 'Russian Seedling' (589312), 'Jonafree' (589962), 'Cortland' (588848), 'Yellow Transparent' (588859), 'Viking' (589434), 'Lady' (589053), 'Jonathan' (890185), 'Virginiagold' (588778), 'Trent' (589490), 'Delicious' (589841), 'Poeltsamaa Winter Apple' (383515), 'Haralson' (589469), and 'Granny Smith' (588880). The origin and main features of all listed accessions can be found at npgsweb.ars-grin.gov.

\subsection{Field-Collection of Leaf Samples}

Undamaged apple (Malus spp.) leaves of various genotypes in a specific age range (i.e., fully-expanded of leaf positions 1 - 8) were collected throughout the growing season (July-Sept., 2011). Whole leaves were excised with scissors in the field at the petiole (distally), just above the stipules. While in the field petioles were inserted into watersoaked Oasis foam housed in a small cooler in which they were transported to the laboratory.

\subsection{Leaf-Disc Bioassay}

Whole leaves of 'Red Delicious' were collected as described above from an orchard at the Tree Fruit Research Extension Center, Wenatchee, WA. Leaf discs were punched out using a brass cork borer (ca. $2.5 \mathrm{~cm}$ diameter). A leaf disc and one neonate $(<24 \mathrm{hr}$ old) larva were placed in a small sterile Petri dish $(50 \times 9 \mathrm{~mm})$. Observations were made daily, and larval development and mortality recorded. Control larvae were kept individually in the same-type Petri dish arena, but fed pinto bean diet (ca. $4.5 \mathrm{~g} \pm 0.3 \mathrm{~g}$ ). Data from OBLR fed on the pinto bean diet were used to generate a developmental profile for this species.

\subsection{Leaf-Weight Experiment}

Whole leaves of 'Red Delicious' were collected from the same orchard and method described above. Each leaf was weighed (mg), and separated into three treatments. Using a sterile vented Petri dish $(94 \mathrm{~mm} \times 16 \mathrm{~mm})$ as an experimental arena a leaf 1) either received no water, 2 ) had the petiole inserted into Oasis foam (ca. $2.5 \mathrm{~cm}^{3}$ ) soaked with 
water and recharged every other day, following Wearing and Colhoun [9], or 3) had the petiole suspended in a $1.5-\mathrm{ml}$ Eppendorf vial filled with water, and recharged as needed. After seven 24-h periods each leaf was weighed and data recorded.

\subsection{Pinto Bean Diet Bioassay}

A pinto bean diet was used to assess OBLR colony quality and as a non-apple control to quantify OBLR development and mortality. OBLR larvae (neonate $<24 \mathrm{~h}$ old) were placed individually in a small sterile Petri dish $(50 \times 9 \mathrm{~mm})$ and provided ca. 4.5 grams of pinto bean diet. Larvae were initially checked daily to determine establishment on the diet then were checked every seven days along with larvae on apple-leaf bioassay as a non-apple control.

\subsection{Whole-Leaf Bioassay}

Whole leaves of different apple genotypes (see above) were collected as described above from WSU Sunrise Research Orchard, Rock Island, WA. The petiole of each leaf was inserted through a hole pierced through the cap of a 2-ml Eppendorf vial filled with water. A single hole was made through the sidewall of a Petri dish (round, non-vent, sterile, $94 \times 16 \mathrm{~mm})$ using a brass cork borer $(9.5 \mathrm{~mm})$ heated by flame. The Eppendorf vial with the leaf was fitted through the hole in the Petri dish such that the leaf was inside the Petri dish and the Eppendorf vial protruded outward. Teflon tape was used to wrap around the base of the Eppendorf vial to secure a tight fit and to prevent neonate larvae from escaping. Water was recharged as needed to maintain a water supply to the leaf. Between 30 and 33 larvae were used for each apple genotype.

Initially each leaf was exposed to four or five neonates. After seven days surviving larvae from the old arenas were transferred in pairs to new arenas each with a new leaf. After another seven days single surviving larvae were transferred to new arenas with a new leaf. Thereafter, at seven-day intervals, surviving larvae were transferred to a new arena with a new leaf. Petri dishes representing each apple accession were stacked vertically (Eppendorf vial at 12 O'clock position) in disposable aluminum foil baking pans $(10 \times 20 \times 6 \mathrm{~cm})$ and stored in an environmental room under constant temperature $\left(23^{\circ} \mathrm{C} \pm 2^{\circ} \mathrm{C}\right)$, relative humidity $(73 \%)$, and photoperiod (16L: 8D). Larger square Petri dishes $(120 \times 120 \times 17 \mathrm{~mm})$ were used as necessary to accommodate larger leaves as the season progressed.

At each seven-day evaluation, the larval stage (instar) was recorded by observing the presence of shed head capsules following a molt and relative head-capsule size, along with mortality. Late larval instars were checked every day to record pupation day, which was converted to development rate (1/day) for analysis. Twenty-four hrs after pupation, a period to allow hardening of the pupal cuticle to reduce risk of injury, the pupal weight and sex were recorded. To determine sex, males display four sclerotized abdominal segments ventrally viewed between the tips of the forewings and genital/anal segment, while females display only three. Pupae were observed daily and the number of days to adult emergence was recorded.

Adult moths originating from the same Malus accession were placed inside a cage to allow for mating and oviposition. Each cage was constructed from a 1-gallon jug with 
the top and bottom cut off and covered over with fine mesh screen. Adults were supplied with honey water and sheets of waxed paper as an oviposition substrate. The number of egg masses deposited onto the wax paper was recorded. Egg masses on waxed paper were then placed individually into a small plastic Petri dish $(50 \times 9 \mathrm{~mm})$ until hatch. Following egg hatch Petri dishes containing neonates were stored at $-23^{\circ} \mathrm{C}$ in a freezer until counted at a later date. The number of eggs laid (fecundity) and larvae per egg mass (fertility) were recorded. To arrive at the total number of eggs laid we added the number of hatched larvae to the number of non-hatched eggs, which was determined using a dissecting microscope.

\subsection{Resistance Indices}

We developed three indices by combining categories of data to assess and summarize our results into three simple effects: antixenotic effects (host acceptance), sub-lethal effects (developmental), and lethal effects (mortality). The three indices are sorted from a low index value of zero (susceptible) to a high index value of one (resistant), and are standardized by setting the pinto bean diet control to zero. The index for antixenotic effects was based on host establishment data. To set the index on a scale from zero to one we divided the proportion of surviving larvae on day seven for a given genotype (gntp) that were neither missing nor found wandering in the arena not on the leaf by the same for the control (ctrl), then subtracted the value from one. Because initial sample sizes varied between 30,32, or 33, we modified the Abbott's formula, correcting for genotypic proportion of larvae not established, $\left\{1-\left[\right.\right.$ (proportion survival $\left.^{\text {gntp }}\right) /($ proportion survival $\left.\left.\left.{ }^{\text {ctrl }}\right)\right]\right\}$. The sub-lethal effects index was based on larval and pupal development whereby susceptible apple genotypes were expressed by a fast larval development rate (LDR) and a high pupal weight (PW), while resistant apple genotypes were expressed by a slow LDR and a low PW. To set the scale from zero to one, we first summed LDR $\times$ PW for each individual and divided by sample size (n) to acquire the combined-sex average for each genotype separately. Secondly, we divided this figure by the same for the control. Thirdly, we subtracted that value from one, $\left\{1-\left[\left(\sum^{\mathrm{n}} \operatorname{LDR} \times\right.\right.\right.$ $\left.\left.\left.\mathrm{PW} / \mathrm{n}^{\mathrm{gntp}}\right) /\left(\sum^{\mathrm{n}} \mathrm{LDR} \times \mathrm{PW} / \mathrm{n}^{\mathrm{ctrl}}\right)\right]\right\}$. The lethal effects index was based on the proportion of mortality of OBLR larvae between day seven and day forty-two. To set the scale from zero to one we used the modified Abbott's formula to correct genotypic proportion mortality, $\left\{1-\left[\right.\right.$ (proportion survival $\left.^{\text {ntp }}\right) /\left(\right.$ proportion survival $\left.\left.\left.^{\text {ctrl }}\right)\right]\right\}$.

\subsection{Statistical Analyses}

For each apple genotype, development rate (1/day) of larvae to pupation, pupal weight (mg), and development rate to adulthood were recorded for males and females and subjected to mixed model analyses. Larval development rate data were arcsin square root transformed and pupal weight data were $\log 10$ transformed to achieve normality. As estimates of precision and inference for fixed effects tend to be inadequate for data generated from small sample sizes, the Kenward-Roger mixed-model method was used to reduce small sample size bias and to generate degrees of freedom that produce better test results for mixed linear models [50]. Date that experiments began was assigned as a random effect. This allowed us to adequately test differences in OBLR response (de- 
pendent variable) to a given apple genotype (independent variable). In testing the main effects, the Kenward-Roger mixed-model method generated fixed-effects $F$ statistics. This method also generated differences of least square means $t$ statistics for analyzing specific mean pairwise comparisons (simple effects) for OBLR feeding on different apple genotypes.

Total cumulative percent mortality of OBLR at adulthood, across all treatments, followed a normal distribution. Life-stage specific mortality, across all life stages on apple alone, followed a Poisson distribution. We employed a generalized linear mixed model, blocking for replicate as a random effect. In testing the main effects, the GLIMMIX procedure generated fixed-effects $F$ statistics. This method also generated differences of least square means $t$ statistics for analyzing specific mean pairwise comparisons (simple effects) using the Bonferroni adjustment for multiple comparisons, which generated conservative adjusted $P$ values.

Cumulative larval emergence (number of emerged larvae) at adulthood followed a normal distribution across all treatments over the 34-day period that larvae hatched from eggs. The data were subjected to a mixed model analysis. Experimental date, and day that larvae emerged, were assigned as random effects. Daily reproductive number (the average number of viable offspring produced per day) data were square root transformed to normalize data, and subjected to a mixed model analysis. Date that experiments began was assigned as a random effect. In testing the main effects, the MIXED procedure generated fixed-effects $F$ statistics. This method also generated differences of least square means $t$ statistics for analyzing specific mean pairwise comparisons (simple effects) using the Fisher's Least Significant Difference (LSD) method. All above data as well as linear regression analyses and Pooled $t$ tests were analyzed using SAS statistical software [51].

\section{Results and Discussion}

\subsection{Leaf-Disc Bioassay}

A leaf-disc bioassay has been previously used to evaluate the impact of pesticides against OBLR [21]. In this bioassay leaf discs were removed from foliage treated with pesticides and used to establish concentration-response data to assess resistance of OBLR to pesticides or to follow larval mortality due to the residue decline of a pesticide. These bioassays lasted seven to ten days and untreated control mortality was less than 20\%. The leaf-disc method used in Dunley et al. [21] utilized four leaf discs in each Petri dish whereas we used only one disc in each Petri dish. In our study, by day ten, most (85.9\%) larvae had abandoned the leaf disc corresponding to a significant positive linear relationship between larvae that abandoned the leaf disc and mortality $[y=-0.015$ $\left.+0.71(\mathrm{x}), R^{2}=0.97, \mathrm{~F}=256.9, P<0.0001\right]$. In contrast, larvae fed on the pinto bean diet had developed to the fourth instar by day fourteen and $90.6 \%$ survived to adult. Because of the desiccation of leaf tissue, coupled with leaf damage from coring out leaf discs, we deemed this bioassay method unacceptable for characterizing parameters of natural resistance in apple to OBLR such as mortality, development time, and reproduction.

Leaf-disc bioassays or bioassays with chopped-up leaf tissue have been used in some situations where natural resistance in plants has been studied. For example, the $33-\mathrm{kD}$ 
cysteine proteinase in the whorl tissue of resistant Maize (Zea mays L.) lines is expressed constitutively from larval feeding by the fall armyworm, Spodoptera frugiperda Smith, and by mechanical damage, but not from susceptible Maize lines [52] [53]. Because the resistance mechanism had been previously identified later resistance studies with $S$. frugiperda used chopped-up Maize tissue as opposed to undamaged tissue [54]. In a study designed to screen pepper accession for resistance to the thrips, Frankliniella occidentalis (Pergande) and Thrips parvispinus (Karny), a leaf-disc method was the most suitable test for assessing resistance compared to whole plants or detached leaves [55]. In this case, the leaf disc method worked because thrips readily colonized leaf discs, the bioassay could be scored after only two days, there was a strong correlation between the leaf-disc and detached-leaf methods, and the leaf-disc method was easier to standardized and more convenient than the detached-leaf method.

\subsection{Leaf-Weight Experiment}

Onstad et al. [42] and Wearing and Colhoun [9] developed whole-leaf bioassays using excised leaves placed either in cylindrical glass vials with leaf petioles in floral water tubes, or in Petri dishes with leaf petioles inserted into Oasis foam and recharged with water every other day. After a seven 24-h period, leaves with petioles inserted into Eppendorf vials had an average weight gain of $5.2 \%$ compared to an average weight loss of 7.7\% for leaves with petioles inserted into Oasis foam, a significant difference of $12.9 \%$ (Pooled $t$ test, $d f=17, t=4.35, P=0.0004$ ). Leaves with their petioles inserted into Eppendorf vials appeared healthier than those inserted into Oasis foam, which showed signs of dehydration (J. Schwarz, personal observations). Based on results from the leaf-disc bioassay and the leaf weight study we opted to use excised whole leaves inserted into 2.0-ml Eppendorf vials for our bioassay assessing impact of OBLR feeding on different apple genotypes.

\subsection{Pinto Bean Diet Bioassay}

Data generated from OBLR reared on the pinto bean diet provided a timeline for OBLR development (Figure 1). On day 7 OBLR larvae were primarily in the second instar, in the fourth instar on day 14 , in the fifth or sixth instar on day 21 , and mostly pupae on

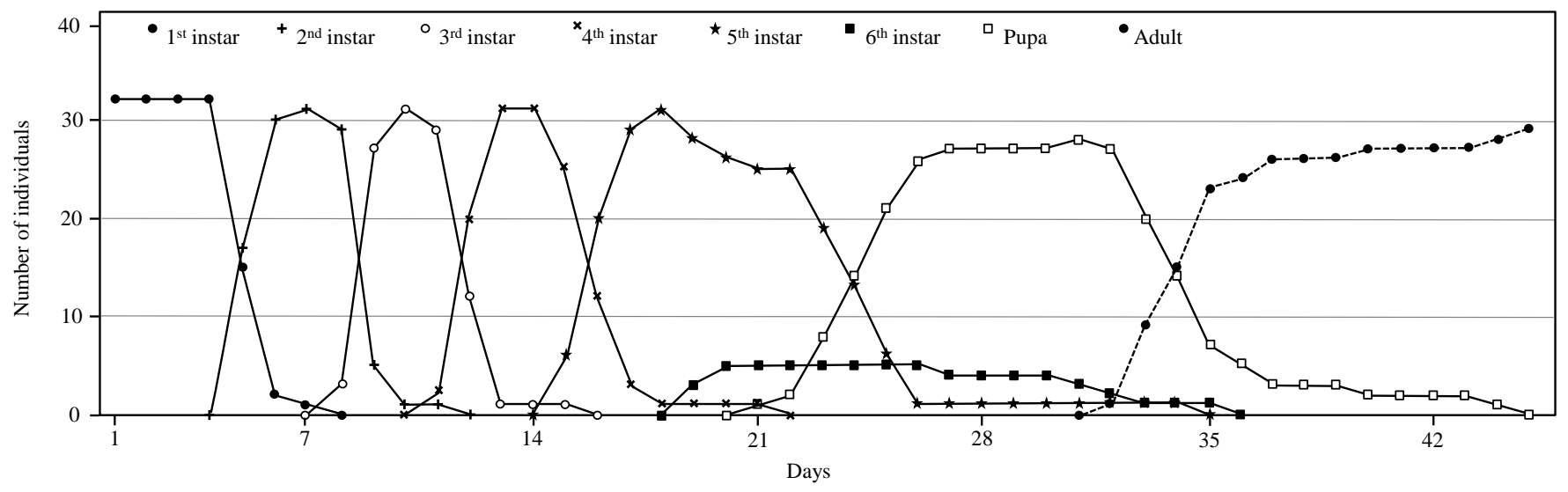

Figure 1. OBLR developmental profile on pinto bean diet across days. 
day 28 . We had a concern that transferring larvae during a molt might increase mortality in the whole-leaf bioassay so we decided to change leaves every seven days, when we would expect most larvae to be between molts.

Larvae reared on the pinto bean diet also provided non-apple comparison or control for OBLR development and served as an independent check on the relative viability of larvae from the colony being used for the whole-leaf bioassay. For example, if larvae did not develop well on the pinto bean diet or suffered high mortality then this would be a signal that the cohort of OBLR was compromised and should not be used in the whole-leaf bioassay. The small size of neonate larvae makes them extremely vulnerable to becoming trapped in free water on surfaces. In our study OBLR mortality reared on three different preparations of pinto bean diet was $43 \%, 37 \%$, and $9 \%$. The variability in OBLR mortality was associated with relative wetness of the different pinto bean preparations. The two preparations with the highest mortality were wetter than normal, which caused free water on Petri dish surfaces where neonate larvae became trapped and died. The third pinto bean diet was typical of a correct preparation, which explained the lower level or mortality. In light of these results we used the pinto bean diet with $9 \%$ mortality as our non-apple control for statistical analyses. In future studies extra care must be taken to minimize water condensation in any of the bioassay methods. Transferring neonate larvae to treatments using a fine camel hairbrush can also result in injury and increased mortality. The best method of capturing neonates is to lift them from the substrate by a silk strand they produce when disturbed, and not by lifting their body directly with the brush.

\subsection{Whole-Leaf Bioassay}

As expected, apple resistance was expressed in OBLR as reduced host acceptance, increased larval development time, decreased pupal weight, higher mortality, and reduced fecundity and fertility.

\subsection{Developmental Parameters}

When challenging OBLR on apple we observed gender-specific differences in levels of performance. For example, when we pooled our data across all the apple genotypes, male larvae developed faster to pupation (30.9 days, $\mathrm{F}=25.5, P<0.0001)$ and to adulthood (40.6 days, $\mathrm{F}=20.2, P<0.0001$ ) than females ( 34.6 and 44.3 days, respectively), while female pupae were heavier $(94.3 \mathrm{mg}, \mathrm{F}=118.2, P<0.0001)$ and developed faster (9.6 days, $\mathrm{F}=48.4, P<0.0001$ ) than male pupae (59.7 $\mathrm{mg}$ and 10.2 days, respectively) (Table 1). Similar results were reported for male and female brownheaded leafroller (BHLR), Ctenopseustis obliquana Walker, greenheaded leafroller (GHLR), Planotortrix octo Dugdale, and the lightbrown apple moth (LBAM), Epiphyas postvittana Walker, for larval development and pupal weight [9]. There was also a strong positive linear relationship between larval development to pupation and to adulthood for both males $\left[\mathrm{y}=14.8+0.84(\mathrm{x}), R^{2}=0.92, \mathrm{~F}=229.28, P<0.0001\right]$ and females $[\mathrm{y}=8.88+1.02(\mathrm{x})$, $\left.R^{2}=0.98, \mathrm{~F}=740.63, P<0.0001\right]$. However, because development to adulthood did not deviate from development to pupation for OBLR fed on a given apple genotype, and because pupal mortality was generally very low, we did not use development-to-adulthood 
data as a performance parameter.

Our data showed considerable variability in development time for OBLR larvae fed on different apple genotypes (Table 1). Male larvae fed on 'Poeltsamaa Winter Apple' had the longest development time, 43.5 days, which was not different from 'Yellow Transparent' and 'Viking'. Development time of male larvae fed on 'Florina' was the shortest at 25.1 days, which was not different from 'Granny Smith' or 'Northern Spy'. Female larvae fed on 'Viking' had the longest development time, 49.5 days, which was not different from 'Yellow Transparent' and 'Cortland', though they both represented only one individual. Female larvae fed 'Cox's Orange Pippin' had the shortest development time, 28.7 days, which was not different from 'Granny Smith' as well as larvae fed on several other genotypes. OBLR larval development on 'Granny Smith' was similar to larvae reared on the pinto bean diet.

Table 1. OBLR variability in average larval development time in response to different apple genotypes.

\begin{tabular}{|c|c|c|c|c|c|c|c|c|c|}
\hline \multicolumn{5}{|c|}{ Males } & \multicolumn{5}{|c|}{ Females } \\
\hline $\begin{array}{c}\text { Apple } \\
\text { Genotype }^{\mathrm{a}}\end{array}$ & $\mathrm{n}^{\mathrm{b}}$ & $\begin{array}{l}\text { Mean days }{ }^{1} \\
\text { to pupation }\end{array}$ & $\mathrm{SE}$ & Grouping $^{c}$ & $\begin{array}{c}\text { Apple } \\
\text { Genotype }^{a}\end{array}$ & $\mathrm{n}^{\mathrm{b}}$ & $\begin{array}{l}\text { Mean days }{ }^{1} \\
\text { to pupation }\end{array}$ & $\mathrm{SE}$ & Grouping $^{c}$ \\
\hline $\mathrm{FL}$ & 9 & 25.1 & 0.35 & A & $\mathrm{CX}$ & 3 & 28.7 & 0.67 & A \\
\hline $\mathrm{PB}$ & 13 & 25.2 & 0.32 & A & GS & 10 & 29.5 & 0.93 & A \\
\hline GS & 7 & 27.3 & 1.61 & $\mathrm{AB}$ & $\mathrm{PB}$ & 16 & 30.6 & 0.93 & A \\
\hline NS & 1 & 28.0 & 0 & $\mathrm{ABCDEF}$ & FL & 14 & 32.1 & 0.37 & $\mathrm{AB}$ \\
\hline TR & 5 & 28.2 & 0.49 & $\mathrm{BCD}$ & $\mathrm{RP}$ & 6 & 31.5 & 0.58 & $\mathrm{AB}$ \\
\hline PR & 6 & 28.3 & 0.20 & $\mathrm{BC}$ & TR & 3 & 32.7 & 1.45 & $\mathrm{ABCDE}$ \\
\hline RS & 7 & 28.4 & 0.61 & $\mathrm{BC}$ & RS & 10 & 32.8 & 1.90 & $\mathrm{ABC}$ \\
\hline LA & 1 & 29.0 & 0 & $\mathrm{ABCDEF}$ & $\mathrm{DE}$ & 6 & 32.8 & 0.91 & $\mathrm{ABCD}$ \\
\hline $\mathrm{DE}$ & 8 & 29.5 & 0.80 & $\mathrm{BCDE}$ & JO & 8 & 33.8 & 2.19 & $\mathrm{ABCD}$ \\
\hline HA & 8 & 29.6 & 0.98 & BCDE & $\mathrm{RF}$ & 4 & 33.3 & 2.17 & $\mathrm{ABCDE}$ \\
\hline JF & 9 & 30.2 & 0.98 & BCDE & HA & 6 & 34.7 & 1.08 & BCDEF \\
\hline $\mathrm{CX}$ & 14 & 30.2 & 1.05 & $\mathrm{CDE}$ & JF & 2 & 35.5 & 1.50 & ABCDEF \\
\hline $\mathrm{CO}$ & 6 & 33.2 & 2.91 & DEF & $\mathrm{CO}$ & 1 & 37.0 & 0 & ABCDEFG \\
\hline JO & 7 & 32.5 & 0.92 & $\mathrm{EF}$ & $\mathrm{PO}$ & 9 & 37.4 & 0.97 & DEF \\
\hline $\mathrm{RF}$ & 3 & 32.7 & 0.88 & CDEF & AN & 3 & 39.0 & 1.53 & DEF \\
\hline AN & 3 & 33.8 & 1.00 & CDEF & VG & 5 & 39.2 & 1.39 & $\mathrm{EF}$ \\
\hline VG & 5 & 34.2 & 3.31 & $\mathrm{EF}$ & LI & 5 & 41.6 & 5.38 & $\mathrm{~F}$ \\
\hline LI & 6 & 34.0 & 2.53 & $\mathrm{EF}$ & $\mathrm{YT}$ & 1 & 43.0 & 0 & CDEFG \\
\hline VK & 2 & 34.5 & 1.50 & EFG & VK & 4 & 49.5 & 1.94 & G \\
\hline YT & 2 & 37.0 & 2.00 & FG & NS & 0 & - & - & \\
\hline $\mathrm{PO}$ & 6 & 43.5 & 6.17 & G & LA & 0 & - & - & \\
\hline Total $^{\mathrm{d}}$ & 115 & 30.9 & 0.56 & & Total $^{\mathrm{d}}$ & 100 & 4.60 & 0.64 & \\
\hline
\end{tabular}

${ }^{a}$ Apple genotypes used: Antonovka 1.5 (AN), PRI 1346-2 (PR), Redfree (RF), Florina (FL), Cox's Orange Pippin (CX), Northern Spy (NS), Liberty (LI), Russian Seedling (RS), Jonafree (JF), Cortland (CL), Yellow ransparent (YT), Viking (VK), Lady (LA), Jonathan (JO), Virginiagold (VG), Trent (TR), Delicious (DE), Poeltsamaa Winter Apple (PO), Haralson (HA), and Granny Smith (GS). Artificial diet: Pinto Bean (PB); ${ }^{b} \mathrm{n}=$ survivors used to collect data; ${ }^{\mathrm{c}}$ Grouping $=$ letter of different grouping in same column are significantly different (LSD, $\left.\alpha<0.05\right)$; ${ }^{\mathrm{d}}$ Total $=$ total genotypes combined. ${ }^{1}$ Data were converted to rate (1/day) and arcsine square root transformed for analysis; (female): Num. df 18, Den. df 96.4, F = 4.86, $P<0.0001$; (male): Num. df 20, Den. df 105, F $=6.92, P<0.0001$. Data presented as mean days for larvae to pupate. 
Our data showed considerable variability in pupal weight for OBLR larvae fed on different apple genotypes (Table 2). Male larvae fed on 'Lady' had the lowest pupal weight, $39.1 \mathrm{mg}$, which did not differ from 'Cortland' and 'Liberty' as well as larvae fed on several other genotypes, which also had some of the longest development times. Male larvae fed on 'Yellow Transparent' had the highest pupal weight, $73.1 \mathrm{mg}$, and did not differ from 'Granny Smith' as well as larvae fed on several other genotypes, which also had some of the shortest development times.

Female larvae that fed on 'Jonafree' had the lowest pupal weight, $39.3 \mathrm{mg}$, and did not differ from those fed on 'Cortland' and 'Liberty', which coincided with long development times. Female larvae fed on 'Yellow Transparent' had the highest pupal weight, $161.7 \mathrm{mg}$, and did not differ from 'Trent' and 'Granny Smith' as well as larvae

Table 2. OBLR variability in average pupal weight in response to different apple genotypes.

\begin{tabular}{|c|c|c|c|c|c|c|c|c|c|}
\hline \multicolumn{5}{|c|}{ Males } & \multicolumn{5}{|c|}{ Females } \\
\hline $\begin{array}{c}\text { Apple } \\
\text { Genotype }^{\mathrm{a}}\end{array}$ & $n^{\mathrm{b}}$ & $\begin{array}{l}\text { Mean pupa }{ }^{1} \\
\text { weight (mg) }\end{array}$ & SE & Grouping $^{c}$ & $\begin{array}{c}\text { Apple } \\
\text { Genotype }^{\mathrm{a}}\end{array}$ & $\mathrm{n}^{\mathrm{b}}$ & $\begin{array}{l}\text { Mean pupa }{ }^{1} \\
\text { weight (mg) }\end{array}$ & SE & Grouping \\
\hline $\mathrm{PB}$ & 13 & 102.2 & 5.74 & A & $\mathrm{PB}$ & 16 & 178.1 & 10.33 & A \\
\hline YT & 2 & 73.1 & 2.70 & $\mathrm{ABC}$ & YT & 1 & 161.7 & 0 & $\mathrm{AB}$ \\
\hline GS & 7 & 72.5 & 4.10 & B & $\mathrm{TR}$ & 3 & 133.3 & 2.93 & $\mathrm{AB}$ \\
\hline HA & 8 & 71.7 & 3.25 & B & GS & 10 & 118.6 & 8.26 & B \\
\hline JO & 7 & 70.6 & 4.24 & $\mathrm{BD}$ & PR & 6 & 114.1 & 2.92 & B \\
\hline $\mathrm{FL}$ & 9 & 70.5 & 1.73 & $\mathrm{BD}$ & JO & 8 & 112.1 & 11.05 & $\mathrm{BC}$ \\
\hline TR & 5 & 68.8 & 3.54 & $\mathrm{BC}$ & $\mathrm{DE}$ & 6 & 107.5 & 6.03 & $\mathrm{BC}$ \\
\hline NS & 1 & 68.2 & 0 & $\mathrm{ABCE}$ & HA & 6 & 102.4 & 9.44 & $\mathrm{BCD}$ \\
\hline PR & 6 & 67.0 & 2.03 & $\mathrm{BC}$ & $\mathrm{FL}$ & 14 & 100.8 & 1.34 & $\mathrm{BCD}$ \\
\hline $\mathrm{DE}$ & 8 & 64.4 & 3.24 & $\mathrm{BCF}$ & $\mathrm{CX}$ & 3 & 94.7 & 5.10 & $\mathrm{BCDE}$ \\
\hline $\mathrm{RF}$ & 3 & 61.9 & 8.60 & $\mathrm{BCE}$ & VG & 5 & 87.3 & 13.01 & CDEFG \\
\hline RS & 7 & 58.2 & 6.93 & BCE & $\mathrm{PO}$ & 9 & 86.6 & 7.08 & $\mathrm{CDEF}$ \\
\hline $\mathrm{CX}$ & 14 & 52.2 & 3.19 & E & RS & 10 & 75.4 & 7.12 & EFGH \\
\hline $\mathrm{PO}$ & 6 & 52.0 & 6.38 & $\mathrm{EF}$ & AN & 3 & 73.6 & 2.80 & DEFGH \\
\hline VG & 5 & 51.3 & 9.99 & E & VK & 4 & 67.3 & 13.15 & FGH \\
\hline AN & 3 & 49.2 & 1.95 & $\mathrm{CE}$ & $\mathrm{RF}$ & 4 & 66.4 & 11.62 & GH \\
\hline VK & 2 & 48.3 & 4.75 & $\mathrm{CDE}$ & LI & 5 & 58.5 & 5.80 & $\mathrm{HI}$ \\
\hline LI & 6 & 48.2 & 8.32 & E & $\mathrm{CO}$ & 1 & 56.4 & 0 & EFGHI \\
\hline $\mathrm{JF}$ & 9 & 48.0 & 4.33 & $\mathrm{E}$ & $\mathrm{JF}$ & 2 & 39.3 & 2.00 & I \\
\hline $\mathrm{CO}$ & 6 & 46.9 & 5.28 & E & NS & 0 & - & - & \\
\hline LA & 1 & 39.1 & 0 & $\mathrm{EF}$ & LA & 0 & - & - & \\
\hline Total $^{\mathrm{d}}$ & 115 & 59.7 & 1.46 & & Total $^{\mathrm{d}}$ & 100 & 94.3 & 2.95 & \\
\hline
\end{tabular}

${ }^{\mathrm{a}}$ Apple genotypes used: see footnote Table $1 ;{ }^{\mathrm{b}} \mathrm{n}=$ survivors used to collect data; ${ }^{\mathrm{c}}$ Grouping $=$ letter of different grouping in same column are significantly different (LSD, $\alpha<0.05) ;{ }^{\mathrm{d}}$ Total = total genotypes combined; ${ }^{1} \mathrm{Data}$ were Log10 transformed; (female): Num. df 18, Den. df 96.4, F = 10.93, $P<0.0001$; (male): Num. df 20, Den. df 105, F = $6.14, P<0.0001$. Data presented as mean milligrams per pupa. 
fed on several other genotypes, which coincided with some of the shortest larval development times. Though the single female surviving on 'Yellow Transparent' had the highest pupal weight, it also had a very long larval development time of 43 days. There was a significant negative linear relationship between pupal weight and development time for males $\left[\mathrm{y}=108.75+-1.53(\mathrm{x}), R^{2}=0.21, \mathrm{~F}=5.07, P=0.036\right]$ and a weak negative linear relationship for females [y $=168.64+-2.03(\mathrm{x}), R^{2}=0.088, \mathrm{~F}=1.65, P=0.22$ ], suggesting that as larvae take longer to develop they tend to have lower pupal weights.

There are very few published articles that report resistance of apple genotypes against OBLR. Onstad et al. [42] provided information for OBLR development and mortality on commercial apple varieties, but none of these varieties were used in our study. In New Zealand, 'Liberty' was considered susceptible to BHLR, GHLR, and LBAM for which combined-sex larval development times averaged 30.1, 26.3, and 34.8 days, respectively, and male and female pupal weights averaged $30.4 \mathrm{mg}$ and $38.2 \mathrm{mg}$ (BHLR), $47.4 \mathrm{mg}$ and $68.0 \mathrm{mg}$ (GHLR), and $22.8 \mathrm{mg}$ and $41.0 \mathrm{mg}$ (LBAM), respectively [9]. Our OBLR combined-sex data for average larval development time fed on 'Liberty' was 37.8 days, which was longer than those reported for New Zealand leafrollers, and the average male and female pupal weights were $48.2 \mathrm{mg}$ and $58.5 \mathrm{mg}$, respectively. That ' $\mathrm{Li}$ berty' led to relatively long development times and low pupal weights for OBLR compared to other apple genotypes we evaluated suggests 'Liberty' expresses some level of resistance.

Wearing and Colhoun [9] reported average pupal weights of male and female LBAM fed on 'Granny Smith' of $23.8 \mathrm{mg}$ and $31.3 \mathrm{mg}$, respectively, and a combined-sex larval development time of 39.7 days. But no BHLR larvae survived when fed on 'Granny Smith'. Their research eventually led to the identification of the dominant putative gene, Cob1, conferring resistance in the apple cultivar 'Prima' [43]. In our study, 'Granny Smith' led to one of the shortest combined-sex larval development times, 28.6 days, and among the heaviest pupal weights for both males and females, $72.5 \mathrm{mg}$ and $118.6 \mathrm{mg}$, respectively, indicating it's susceptibility to OBLR.

Differential development times between male and female OBLR may result in temporal separation of activity that mate location may actually limit successful mating. For example, female larvae fed on 'Viking' on average pupated fifteen days later than males, while male larvae fed on 'Poeltsamaa Winter Apple' on average pupated six days later than females. Genotypic effects that delay development of males or females could result in reduced mating due to the fact that fewer individuals would be present at a time appropriate for mating. An extended time of larval development may signal that poor nutrition or antibiosis is at work. A longer development time, even if it does not lead to increased mortality, would be beneficial because larvae would be exposed to other mortality factors, especially the activities of biological control agents (i.e., predators and parasitoids), which have been shown to positively modulate their consumption behavior towards nutrition-deficient prey [56]. An extended period of larval development could also reduce the possibility of having two complete successful OBLR generations, thereby impacting larval fitness during the early fall, when they prepare for and enter overwintering diapause (as second or third instars) as well as post-overwintering survival. Such sub-lethal impacts as those discussed here may help lower OBLR popula- 
tions resulting in a reduced need for chemical controls. However, an extended period of larval development could have a negative side. For instance, degree-day models that are based on a normal or typical development rate might not accurately predict the timing of control treatments targeting a specific life stage, which could mean that models would have to be, fine-tuned to resistant cultivars that impact OBLR development.

Like slow development, low weight can have negative consequences on OBLR. Because smaller insects have a higher surface-to-body mass ratio, they experience faster dehydration and higher metabolism [57] [58]. Smaller insects have higher foraging rates to compensate for nutritional demands, which exposes them to more encounters with predators and thus higher probabilities of being consumed [59] [60], resulting in enhanced biocontrol. Moreover, smaller insects produce fewer gametes. In our study there was a significant positive linear relationship between female pupal weight and the number of eggs produced $\left[\mathrm{y}=-21.47+40.20(\mathrm{x}), R^{2}=0.50, \mathrm{~F}=17.3, P=0.0007\right]$.

\subsection{Mortality}

There was significant variability $(\mathrm{F}=17.58, P<0.0001)$ in cumulative mortality (larvae to adult emergence) for OBLR feeding on different apple genotypes (Table 3 ). Across

Table 3. OBLR variability in cumulative mortality in response to different apple genotypes.

\begin{tabular}{|c|c|c|c|c|}
\hline Apple Genotype $^{a}$ & $\mathrm{n}^{\mathrm{b}}$ & Percent ${ }^{1}$ mortality & SE & Grouping $^{\mathrm{c}}$ \\
\hline LA & 33 & 97.0 & 2.98 & A \\
\hline NS & 30 & 96.7 & 3.28 & $\mathrm{AB}$ \\
\hline $\mathrm{YT}$ & 33 & 90.9 & 5.00 & $\mathrm{AB}$ \\
\hline VK & 33 & 81.8 & 6.71 & $\mathrm{ABC}$ \\
\hline $\mathrm{CO}$ & 30 & 80.0 & 7.3.0 & $\mathrm{ABCD}$ \\
\hline RF & 30 & 80.0 & 7.3.0 & $\mathrm{ABCD}$ \\
\hline AN & 30 & 80.0 & 7.3.0 & $\mathrm{ABCD}$ \\
\hline TR & 32 & 75.0 & 7.65 & $\mathrm{ABCD}$ \\
\hline VG & 33 & 69.7 & 8.00 & BCDE \\
\hline JO & 33 & 63.6 & 8.37 & $\mathrm{CDEF}$ \\
\hline LI & 30 & 66.7 & 8.61 & $\mathrm{CDEF}$ \\
\hline JF & 30 & 66.7 & 8.61 & CDEF \\
\hline CX & 30 & 63.3 & 8.8 .0 & CDEF \\
\hline $\mathrm{PO}$ & 32 & 59.4 & 8.68 & CDEF \\
\hline $\mathrm{DE}$ & 32 & 56.3 & 8.77 & DEF \\
\hline HA & 32 & 56.3 & 8.77 & DEF \\
\hline $\mathrm{PR}^{\mathrm{d}}$ & 29 & 58.6 & 9.15 & DEF \\
\hline GS & 32 & 46.9 & 8.82 & $\mathrm{EF}$ \\
\hline FL & 30 & 46.7 & 9.11 & $\mathrm{~F}$ \\
\hline RS & 30 & 46.7 & 9.11 & $\mathrm{~F}$ \\
\hline $\mathrm{PB}$ & 32 & 9.1 & 5.15 & G \\
\hline
\end{tabular}

${ }^{a}$ Apple genotypes used: see footnote Table 1 ; ${ }^{b} \mathrm{n}=$ total number of insects used; ${ }^{\mathrm{c}}$ Grouping = letter of different grouping in same column are significantly different (LSD, $\alpha<0.05) ;{ }^{\mathrm{d}} \mathrm{PR}(\mathrm{n}=29)$ : one fourth-instar larva was accidentally impaled with forceps during handling; ${ }^{1}$ Cumulative percent mortality-larva to adult: Num. $\mathrm{df}=20, \mathrm{Den} . \mathrm{df}$ $=603, \mathrm{~F}=17.58, P<0.0001$. 
all apple genotypes cumulative mortality was $69.2 \%$. Apple genotypes that showed the lowest cumulative mortality (<50\%) were 'Russian Seedling', 'Florina', and 'Granny Smith'. The highest cumulative mortality ( $>90 \%$ ) occurred on 'Lady', 'Northern Spy', and 'Yellow Transparent'. In New Zealand, GHLR fed on 'Jonafree' suffered 38.1\% mortality while LBAM suffered only $17.5 \%$ mortality [61]. In this study OBLR fed on 'Jonafree' suffered $66.7 \%$ mortality.

Our data showed that mortality had a weak positive linear relationship with development time for males $\left[\mathrm{y}=0.51+0.0090(\mathrm{x}), R^{2}=0.12, \mathrm{~F}=2.53, P=0.130\right]$ and females $\left[\mathrm{y}=0.41+0.0109(\mathrm{x}), R^{2}=0.19, \mathrm{~F}=3.95, P=0.060\right]$, and had a weak negative linear relationship with pupal weight for males $\left[\mathrm{y}=0.95+-0.0025(\mathrm{x}), R^{2}=0.10, \mathrm{~F}=2.15, P=\right.$ $0.160]$ and females $\left[\mathrm{y}=0.93+-0.0014(\mathrm{x}), R^{2}=0.14, \mathrm{~F}=2.70, P=0.120\right]$, suggesting that as OBLR larvae take longer to develop and produce smaller pupae (and therefore, adults), survivorship declines. For example, female larvae fed on 'Viking' were the slowest to develop, had among the lowest pupal weight, suffered high cumulative mortality, and produced no offspring.

There was a significant difference in life-stage specific mortality $(\mathrm{F}=38.25, P<$ $0.0001)$ for OBLR feeding on different genotypes while there was no significant difference $(\mathrm{F}=0.98, P=0.4388)$ in any life-stage specific mortality for OBLR feeding on pinto bean. The highest level of mortality was observed in first, $28.8 \%$, and sixth, $31.6 \%$, instars. Reduced larval feeding and wandering off or rejecting the apple-leaf source resulted in high levels of first-instar mortality associated with starvation. For example, OBLR larvae fed on 'Lady' had the highest mortality for first instars, $72.7 \%$, followed by 'Yellow Transparent', 63.6\%, 'Trent', 56.2\%, 'Viking', 54.5\%, 'Delicious', 47.3\%, and 'Virginiagold', 39.4\%. Some first-instar mortality may have been due to mishandling of neonate larvae during their initial transfer to arenas and not rejection of the genotypes as an acceptable host. In addition, OBLR larvae not recovered in the Petri dish arena may have escaped but in our study they were recorded as dead. These concerns have resulted in modifications to the bioassay Petri dish arena and changes in larval handling during transfer in future studies.

The highest level of sixth-instar mortality was from larvae fed on, 'Antonovka 1.5', 40.0\%, 'Cortland', 40.0\%, 'Liberty', 40.0\%, 'Northern Spy', 33.4\%, and 'PRI 1346-2', $27.6 \%$. Mortality of fifth, $14.5 \%$, and second, $9.4 \%$, instar larvae were similar, though some fifth instar larvae showed considerable mortality when fed on 'Redfree', $20.0 \%$, 'Northern Spy', 20.0\%, 'Antonovka', 23.3\%, and 'Cox's Orange Pippin', 26.7\%, as did second instar larvae fed on 'PRI 1346-2', 20.0\%. Third and fourth instar larvae had the lowest mortality, $3.7 \%$ and $5.4 \%$. These results indicate that apple genotypes with a lethal antibiotic resistance had the greatest impact on early and late instars. While pupal mortality was generally low, $10.3 \%$, it was relatively high for larvae fed on 'Cox's Orange Pippin', 20.0\%, and 'Florina', 23.3\%, and may represent another level or form of resistance expressed in this life-stage.

\subsection{Reproduction}

Collecting individual female fecundity and fertility data was not possible with the method used, as we could not be certain of how many females contributed to the data for a 
given genotype. However, there was significant variability $(\mathrm{F}=109.95, P<0.0001)$ in cumulative larval emergence from egg masses for OBLR that produced offspring (Table 4). On apple, the total number of egg masses laid ranged from 58 for OBLR fed on 'Granny Smith' to zero for those fed on 'Lady', 'Northern Spy', 'Viking', 'Cortland', and 'Jonafree', while the average number of eggs per egg mass ranged from 231.4 on 'Trent' to 55.0 on 'Redfree'. Our data shows that the proportion of emerged viable larvae from egg masses (i.e., proportion of viable eggs) has a significant positive linear relationship with the number of eggs per egg mass $\left[\mathrm{y}=0.65885+0.03360(\mathrm{x}), R^{2}=0.23, \mathrm{~F}=72.76, P\right.$ $<0.0001$ ] suggesting that larger egg masses that have a higher number of eggs produce a higher proportion of eggs that are viable (i.e., emerged larvae) than smaller egg masses with fewer eggs. The highest absolute number of hatched larvae, 6373, was from OBLR fed on 'Granny Smith', and was nearly identical in number for OBLR fed on pinto bean, 6366.

Table 4. OBLR variability in cumulative larval emergence from egg masses in response to different apple genotypes.

\begin{tabular}{|c|c|c|c|c|c|c|c|c|}
\hline $\begin{array}{c}\text { Apple } \\
\text { Genotype }^{\mathrm{a}}\end{array}$ & $\begin{array}{c}\text { Number } \\
\text { males }\end{array}$ & $\begin{array}{l}\text { Number } \\
\text { females }\end{array}$ & $\begin{array}{c}\text { Total egg } \\
\text { masses } \\
\text { laid }\end{array}$ & $\begin{array}{c}\text { Mean } \\
\text { eggs per } \\
\text { mass }^{b}\end{array}$ & $\begin{array}{c}\text { Total viable } \\
\text { offspring } \\
\text { (or eggs) }\end{array}$ & $\begin{array}{c}\text { Mean } \\
\text { cumulative } \\
\text { emergence }^{1}\end{array}$ & SE & Grouping $^{\mathrm{d}}$ \\
\hline GS & 7 & 10 & 58 & 134.9 & 6373 & 4732.7 & 409.3 & A \\
\hline PB & 13 & 16 & 63 & 143.0 & 6366 & 4431.2 & 450.1 & B \\
\hline $\mathrm{DE}$ & 8 & 6 & 26 & 206.0 & 3631 & 2343.9 & 270.3 & $\mathrm{C}$ \\
\hline $\mathrm{TR}$ & 5 & 3 & 14 & 231.4 & 2902 & 1866.1 & 210.8 & D \\
\hline JO & 5 & 7 & 29 & 155.2 & 3287 & 1863.6 & 237.2 & $\mathrm{DE}$ \\
\hline PR & 6 & 6 & 13 & 179.8 & 2224 & 1710.2 & 142.4 & $\mathrm{DE}$ \\
\hline $\mathrm{HA}$ & 8 & 6 & 21 & 159.6 & 2569 & 1497.0 & 191.4 & $\mathrm{E}$ \\
\hline RS & 6 & 10 & 10 & 178.1 & 1243 & 972.3 & 79.8 & $\mathrm{~F}$ \\
\hline $\mathrm{PO}$ & 4 & 9 & 23 & 124.7 & 1712 & 932.4 & 137.6 & $\mathrm{~F}$ \\
\hline FL & 8 & 8 & 9 & 138.0 & 997 & 822.5 & 52.3 & $\mathrm{~F}$ \\
\hline AN & 3 & 3 & 10 & 94.2 & 713 & 379.8 & 56.6 & $\mathrm{H}$ \\
\hline YT & 2 & 1 & 6 & 196.8 & 1044 & 316.6 & 73.4 & GH \\
\hline VG & 5 & 4 & 2 & 153.1 & 244 & 143.5 & 20.9 & GH \\
\hline LI & 5 & 5 & 6 & 112.2 & 222 & 142.8 & 16.8 & GH \\
\hline CX & 9 & 2 & 1 & 122.0 & 67 & 45.3 & 5.5 & $\mathrm{H}$ \\
\hline $\mathrm{RF}$ & 3 & 3 & 1 & 55.0 & 0 & 0 & 0 & $\mathrm{H}$ \\
\hline $\mathrm{JF}$ & 9 & 1 & 0 & - & - & - & - & \\
\hline $\mathrm{CO}$ & 5 & 1 & 0 & - & - & - & - & \\
\hline VK & 2 & 4 & 0 & - & - & - & - & \\
\hline NS & 1 & 0 & 0 & - & - & - & - & \\
\hline LA & 1 & 0 & 0 & - & - & - & - & \\
\hline
\end{tabular}

${ }^{\mathrm{a} A p p l e ~ g e n o t y p e s ~ u s e d: ~ s e e ~ f o o t n o t e ~ T a b l e ~} 1$; ${ }^{\mathrm{b}}$ Average number of total eggs (viable and non-viable) per egg mass; ${ }^{\mathrm{d}}$ Grouping = letter of different grouping in same column are significantly different (LSD, $\left.\alpha<0.05\right)$; ${ }^{1}$ Cumulative larval emergence data followed a normal distribution. Num. $\mathrm{df}=15$, Den. $\mathrm{df}=396, \mathrm{~F}=109.95, P<0.0001$. Cumulative emergence data analyzed only for OBLR that laid eggs. 
There was also significant variability for the daily reproductive number $(\mathrm{F}=207.42$, $P<0.0001)$ for OBLR when challenged on different apple genotypes over a 14-day period (Table 5). OBLR fed on 'Granny Smith' produced on average the highest number of larvae per day, 483.8, and was not different than those fed on pinto bean, 492.3. For OBLR that laid eggs, those fed on 'Cox's Orange Pippin' produced on average the fewest offspring per day, 15.6 .

When female insects exhibit optimal parameters for development and display low mortality they tend to produce more eggs (fecundity) and have a higher likelihood of successful mating, resulting with more offspring production (fertility). In our study, there were significant positive linear relationships between female pupal weights and collective female fecundity $\left[\mathrm{y}=-2656.37+51.94(\mathrm{x}), R^{2}=0.48, \mathrm{~F}=15.5, P=0.0011\right]$ and fertility [y $\left.=-2112.47+40.20(\mathrm{x}), R^{2}=0.50, \mathrm{~F}=17.26, P=0.0007\right]$. There were also significant negative linear relationships between female larval development

Table 5. OBLR Variability in daily reproductive number in response to different apple genotypes.

\begin{tabular}{|c|c|c|c|c|}
\hline \multicolumn{5}{|c|}{ Daily } \\
\hline Apple Genotype ${ }^{a}$ & Number of Females ${ }^{\mathrm{b}}$ & Reproductive Number ${ }^{1}$ & SE & Grouping $^{c}$ \\
\hline $\mathrm{PB}$ & 6 & 492.3 & 34.0 & A \\
\hline GS & 10 & 483.8 & 22.0 & A \\
\hline $\mathrm{DE}$ & 6 & 294.9 & 17.7 & B \\
\hline $\mathrm{PR}$ & 6 & 291.1 & 29.7 & B \\
\hline JO & 7 & 235.2 & 14.7 & $\mathrm{C}$ \\
\hline $\mathrm{TR}$ & 3 & 206.3 & 11.1 & $\mathrm{CD}$ \\
\hline HA & 6 & 179.9 & 11.0 & $\mathrm{D}$ \\
\hline RS & 10 & 171.6 & 18.6 & $\mathrm{D}$ \\
\hline YT & 1 & 119.2 & 10.7 & $\mathrm{E}$ \\
\hline $\mathrm{PO}$ & 9 & 117.5 & 15.9 & $\mathrm{E}$ \\
\hline FL & 8 & 91.8 & 6.3 & $\mathrm{E}$ \\
\hline AN & 3 & 61.4 & 3.6 & $\mathrm{~F}$ \\
\hline VG & 4 & 56.7 & 16.4 & FG \\
\hline LI & 5 & 35.2 & 6.4 & G \\
\hline $\mathrm{CX}$ & 2 & 15.6 & 4.5 & $\mathrm{H}$ \\
\hline VK & 4 & 0 & 0 & I \\
\hline $\mathrm{RF}$ & 3 & 0 & 0 & I \\
\hline $\mathrm{CO}$ & 1 & 0 & 0 & I \\
\hline JF & 1 & 0 & 0 & I \\
\hline LA & 0 & 0 & 0 & I \\
\hline NS & 0 & 0 & 0 & I \\
\hline
\end{tabular}

${ }^{a}$ Apple genotypes used: see footnote Table 1 ; ${ }^{b}$ Number of surviving females; ${ }^{\mathrm{c}}$ Grouping = letter of different grouping in same column are significantly different (LSD, $\alpha<0.05$ ); ${ }^{1}$ Daily Reproductive Number $=$ average number of viable offspring hatched per day over 14 days. Data were square root transformed; Num. $\mathrm{df}=20$, Den. $\mathrm{df}=273, \mathrm{~F}=207.42$, $P<0.0001$. 
time and collective female fecundity $\left[\mathrm{y}=11224.00+-249.73(\mathrm{x}), R^{2}=0.24, \mathrm{~F}=5.25, P=\right.$ $0.035]$ and fertility $\left[\mathrm{y}=8727.81+-196.02(\mathrm{x}), R^{2}=0.26, \mathrm{~F}=5.9, P=0.03\right]$. Our data also shows that collective female fertility had a significant positive linear relationship with male pupal weight $\left[\mathrm{y}=-5086.57+109.31(\mathrm{x}), R^{2}=0.56, \mathrm{~F}=21.7, P=0.0002\right]$ and a borderline-significant negative linear relationship with male larval development time $\left[\mathrm{y}=8275.10+-206.97(\mathrm{x}), R^{2}=0.20, \mathrm{~F}=4.36, P=0.052\right]$, suggesting that sperm load contributes to the production of viable offspring as it is likely a function of male size. The relationship of fertility response in OBLR as a function of larval development time and pupal weight is not surprising considering that OBLR fed on 'Granny Smith' had high pupal weights, short development times, and the highest daily reproductive number, while OBLR that fed on 'Liberty' had long development times, the lowest pupal weights, and a low daily reproductive number (Table 1, Table 2, Table 5, Figure 2(b)).

In generating the OBLR development profile (Figure 1) our data revealed that not all females lay eggs, even under a high-quality pinto bean diet regimen. We paired male and female adults into individual arenas so were able to gather data on fertility and fecundity per individual (data not reported). We observed that only $76.9 \%(10 / 13)$ of paired females laid egg masses, with an average of two per female. These preliminary results led us to combine all adults from each apple genotype separately into one oviposition chamber to enhance the probability of mating. Moreover, the outcome of these results may or may not reflect resistance when challenged on apple, but rather reflects some component of egg development, courtship, and mating. For example, while larvae fed on either 'Florina' or 'Granny Smith' did not show negative impacts related to growth and development and mortality (Figure 2(b) and Figure 2(c)), relatively few eggs and viable offspring were produced when fed on 'Florina', even in the presence of eight surviving females, resulting with a low daily reproductive number (Table 1, Table 3, Table 4, Table 5). By contrast, the highest number of eggs and offspring were produced on 'Granny Smith'. That the apple-leaf data suggests that apple resistance might be expressed as through suppressed reproduction it is, therefore, likely worth the effort to record reproductive data in future studies.

\subsection{Resistance Indices}

Another way of looking at genotypic-specific effects is to develop indices by combining several factors that might comprise resistance and sorting the indices data from a low index value of zero to a high index value of one (Figure 2). The first index, Figure 2(a) (antixenotic effects), was based on host acceptance, and depicts 'Florina', 'Cox's Orange Pippin', and 'Liberty' as having the highest levels of establishment on the host leaf (low antixenosis), while 'Lady' and 'Yellow Transparent' display the lowest levels of establishment (high antixenosis). If first instar larvae demonstrate a high level of rejection of an apple genotype it would suggest some degree of resistance to OBLR. The first instar larva is a highly dispersive life-stage and is, therefore, vulnerable to finding the right host or conditions favorable for establishment. In our initial arena design some first instar larvae may have escaped the arena or died while wandering before returning to the host leaf and attempting establishment. A more controlled bioassay could be developed specifically to assess first instar colonization of apple genotypes that would minimize wandering or escape from test arenas. 


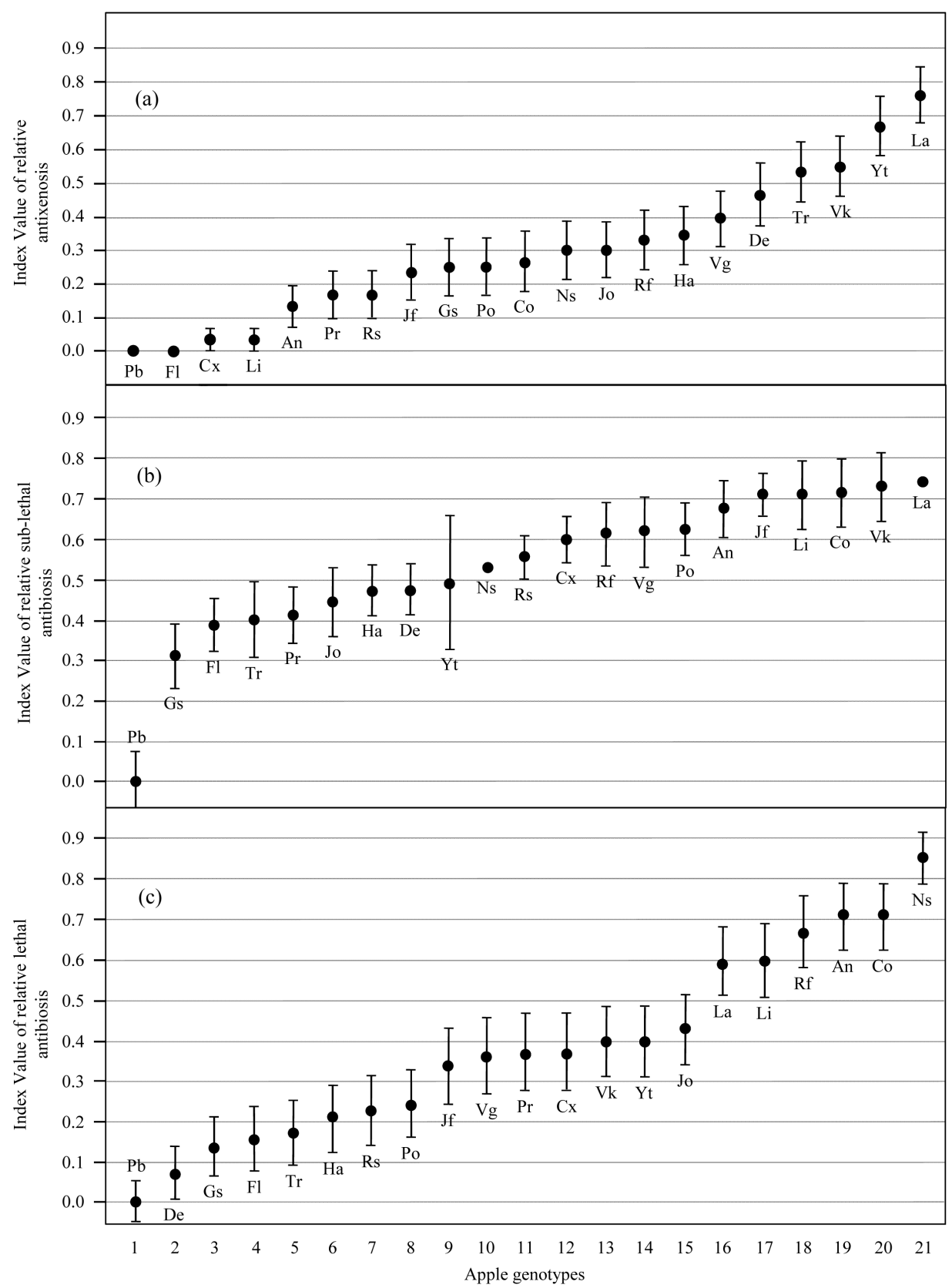

Figure 2. Resistance indices of relative: (a) antixenosis; (b) sub-lethal antibiosis; and (c) lethal antibiosis.

A second index, Figure 2(b) (sub-lethal effects), was based on larval development rate and pupal weight as we saw a negative linear relationship between these two parameters for both males and females (see above), and depicts 'Granny Smith', 'Florina', 'Trent', 'PRI', and 'Jonathan' as having some of the lowest index levels, while 'Lady', 'Viking', 'Cortland', 'Liberty', and 'Jonafree' display some of the highest index levels.

The third index, Figure 2(c) (lethal effects), was based on mortality of OBLR larvae between day seven and day forty-two, and depicts 'Delicious', 'Granny Smith', 'Florina' and 'Trent' as having the lowest index values, while 'Northern Spy' displays the highest index level. Wearing et al. [61] developed a ranking system based on development time 
and pupal weight for three species of leafrollers feeding on different apple genotypes. Their ranking system ranked 'Jonafree' as being susceptible to both GHLR and LBAM. In our sub-lethal index OBLR fed on 'Jonafree' displayed among the highest values based on slow development and small pupae, which would indicate resistance.

Many of the apple genotypes reported here demonstrate a moderate level of resistance similar to 'Delicious', while eight genotypes expressed high levels of resistance. For example, 'Lady' and 'Yellow Transparent' express the highest levels of antixenotic effects, 'Lady', 'Viking', 'Cortland', 'Liberty', and 'Jonafree' express the highest levels of sub-lethal effects, and 'Northern Spy', 'Cortland', and 'Antonovka 1.5' expressed the highest levels of lethal effects. 'Northern Spy' and 'Lady' had no female larvae that fed on them survive to adulthood, and 'Cortland', 'Redfree', 'Jonafree' and 'Viking' produced no viable offspring. Some genotypes reported in this study are also reported to demonstrate resistance against aphids and diseases, and the identified resistance genes are being implemented into breeding programs.

'Northern Spy' appears to be highly resistant to OBLR primarily due to a high level of lethal antibiosis. 'Northern Spy' has been subject to resistance breeding against insects for decades [28] [62]. 'Northern Spy' is the source of the woolly apple aphid (WAA), Eriosoma lanigerum Hausmann, resistance gene, $E r$ [26], which is now designated as Er1 [63]. It has been used in breeding programs for rootstock resistance to WAA, however, the single-gene, $E r 1$, has low durability for WAA resistance [28]. Two other WAA resistance genes in Malus have been identified, Er2 from 'Robusta 5' [64] and Er3 from 'Aotea 1' [65], which led to the validation of markers for and mapping of the WAA resistance genes, $\operatorname{Er} 1, E r 2, E r 3$ [28]. The three $E r$ genes, together with a fourth gene, $E r 4$, allows for pyramiding in breeding programs to increase the durability of WAA resistance [29].

Resistance to the rosy leaf-curling aphid, Dysaphis devecta Walker, is under the control of a single gene, $S d 1$, in 'Cox's Orange Pippin' [66]. Alston and Briggs [66] also showed evidence that 'Northern Spy' provides monogenic resistance to D. devecta and later confirmed that there are four genes providing resistance to three $D$. devecta biotypes, one of which, $S d 2$, provides resistance to biotype 1 only and is from 'Northern Spy' [63] [67]. 'Northern Spy' is also classified as being resistant to Phytophthora cactorum (Lebert \& Cohn), the plant pathogen that causes collar rot [63] [68], and very resistant to fire blight in Rosaceae [69]. Lethal effects of 'Northern Spy' against OBLR in our study may add to the success of resistance breeding into high-quality apple cultivars.

'Antonovka 1.5' appears to express high levels of sub-lethal and lethal effects against OBLR while 'Liberty' displays moderate levels. Selections of 'Antonovka' have been reported to be resistant to apple scab, Venturia inaequalis (Cooke), [63] [70], and both 'Antonovka' and 'Liberty' demonstrate resistance to Alternaria alternata (Fr.), the fungus that causes Alternaria blotch disease [71].

'Yellow Transparent' appears to express a high level of resistance to OBLR due to a high level of antixenosis and a moderate level of lethal antibiosis. 'Yellow Transparent' has been shown to be moderately resistant to the bacterium, Erwinia amylovora (Burrill), which causes fire blight [69].

'Florina' is reported to having low susceptibility to fire blight (E. amylovora) and re- 
sistance to both apple scab ( $V$. inaequalis) and the rosy apple aphid (RAA), Dysaphis plantaginea Passerini [72] [73], while both 'Jonafree' and 'Redfree', known to having apple scab resistance, were both classified as being highly susceptible to the RAA [73]. In our study OBLR larvae displayed good growth and development and low mortality when fed on 'Florina', but adult reproductive output was suppressed, while both 'Jonafree' and 'Redfree' showed a good level of sub-lethal and lethal resistance against OBLR.

The major fire blight QTL has been mapped to linkage group 3 in M. robusta, and explains up to $80 \%$ of the phenotypic variation [74] [75]. However, the QTL mapped to linkage group 7 for fire blight resistance in 'Fiesta' ( $M$. domestica) explains up to $46 \%$ of the phenotypic variation, and has been tracked back to its parent, 'Cox's Orange Pippin' [76] [77]. 'Cox's Orange Pippin' was also considered the source of a resistance gene, $S d 1$, which provides resistance to $D$. devecta biotypes 1 and 2 [66] [67], but is now regarded as the source of the precursor gene (PrSd) to the $S d$ gene in 'Fiesta', its offspring [63]. In our study 'Cox's Orange Pippin' showed a moderately high level of both lethal and sub-lethal resistance to OBLR.

Chewing insects are key pests of apple in Washington and throughout most of the world where apples are grown, requiring high inputs of synthetic pesticides, which leads to the development of pesticide resistance, disruption of biological control, and increases risks to farm workers and the environment. Some of the genotypes tested in this study may represent genotypes in which resistance to OBLR is linked to, or associated with, either disease or aphid resistance. However, because 'Granny Smith' has been shown to be resistant to Alternaria blotch disease while 'Northern Spy' is susceptible [71], may negate any correlation between resistance to OBLR that we observed in this study with resistance to disease or aphids.

\subsection{Future Directions}

There is a considerable amount of variability in the parameters we measured for OBLR fed on different apple genotypes using our whole-leaf bioassay. This method revealed levels of resistance in different apple genotypes against OBLR expressed as host acceptance (antixenosis), mortality (lethal antibiosis), and development (sub-lethal antibiosis), allowing us to partition relative resistance rankings based on these categories. Our whole-leaf bioassay was developed using apple foliage from the end of the summer season, August into September. Wearing et al. [43] reported that the time of growing season strongly influenced the expression of resistance against BHLR between early- and late-summer experiments, but these data were only based on larval survivorship and were both relatively high, $81.2 \%$ early verses $64.9 \%$ late. Therefore, in future studies, we plan to use the whole-leaf bioassay to measure the parameters used in this study during three distinct time periods: spring (May and June), summer (July and August) and fall (September and October). These time periods coincide with key periods when OBLR larvae are feeding on apple trees, when resistance may be differentially expressed across phenology. Because year-to-year variation could have an influence on leafroller and codling moth response to apple genotypes [9] [43] [45], we intend to use our bioassay method to evaluate selected genotypes over multiple years.

Geographic location may also play a role in the expression of resistance. For example, a survey of 160 genotypes from a segregating F1 cross between 'Fiesta' and 'Discovery' 
has shown a lack of correlation in codling moth, Cydia pomonella (Linnaeus), infestations between years and orchard sites [45]. Significant year and site variability, but not phenological variability, in resistance indicates instability of the genome, and the authors argue environmental effects like available rainfall and sunlight as likely explanations. Variability in genome instability expression anticipates challenges for resistance breeding and may not be worth the effort to breed unreliability.

Wearing et al. [43] compared wild verses lab-reared BHLR and found that the labreared BHLR had countered the resistance of 'Prima' that was observed against wildtype BHLR. The OBLR colony used in conducting bioassays in our study was maintained for years on an artificial diet, so it may have a significant effect on response to insects feeding on apple. One way to overcome this concern is to conduct comparative trials with both lab colony and wild populations; however, the labor-intensive nature of our bioassay method would likely constrain the number of apple genotypes that could be screened should it become necessary to test both lab and wild populations of OBLR. Nevertheless, our method identified the commercial cultivar 'Granny Smith' as being susceptible to OBLR, substantiating years of field observations (J. Brunner, personal communication), making it a good candidate for apple-leaf control in future studies.

\section{Acknowledgements}

We thank Ed Mitchell, Terry Collier and Mike Mitchell for their care in managing research plots at the WSU Sunrise Research Orchard near Wenatchee, WA. We thank Kathy Pierre, Josh Milnes and Adrian Marshall for help in maintenance of the leafroller colony and assistance in collecting foliage from apple genotypes and helping collect data. We also thank Dr. Steve Sheppard and Dr. Elizabeth Beers for assistance in reviewing the manuscript. This research was funded in part by a grant from the Washington Tree Fruit Research Commission.

\section{References}

[1] Chapman, P.J. and Lienk, S.E. (1971) Tortricid Fauna of Apple in New York (Lepidoptera: Tortricidae): Including an Account on Apples Occurrence in the State, Especially as a Naturalized Plant. New York State Agricultural Experiment Station, Geneva.

[2] Weires, R. and Riedl, H. (1991) Other Tortricids on Pome and Stone Fruits. In: Van der Geest, L.P.S. and Evenhuis, H.H., Eds., Tortricid Pests. Their Biology, Natural Enemies and Control, Elsevier, New York, 412-434.

[3] Schuh, J. and Mote, D.C. (1948) The Oblique-Banded Leaf Roller on Red Raspberries. Technical Bulletin 13, Oregon Agricultural Experimental Station, Oregon State College, Corvallis.

[4] Carriere, Y. (1992) Larval Dispersal from potential Hosts within a Population of a Generalist Herbivore, Choristoneura rosaceana. Entomologia Experimentalis et Applicata, 65, 11 19. https:/doi.org/10.1111/j.1570-7458.1992.tb01622.x

[5] Beers, E.H., Brunner, J.F., Willett, M.J. and Warner, G.M. (1993) Orchard Pest Management: A Resource Book for the Pacific Northwest. Good Fruit Grower, Yakima.

[6] Madsen, H.F. and Madsen, B.J. (1980) Response of Four Leafroller Species (Lepidoptera: Tortricidae) to Sex Attractants in British Columbia Orchards. Canadian Entomologist, 112, 427-430. https:/doi.org/10.4039/Ent112427-4 
[7] Howitt, A.H. (1993) Common Tree Fruit Pests. Michigan State University Extension, NCR 63.

[8] Ohlendorf, B.L.P. (1999) Integrated Pest Management for Apples and Pears. 2nd Edition, Statewide Integrated Pest Management Project, University of California Division of Agriculture and Natural Resources, Publication 3340.

[9] Wearing, C.H. and Colhoun, K. (1999) Bioassays for Measuring the Resistance of Different Apple Cultivars to the Development of Leafrollers (Lepidoptera: Tortricidae). New Zealand Journal of Crop and Horticultural Science, 27, 91-99.

https:/doi.org/10.1080/01140671.1999.9514085

[10] Brunner, J.F. (1999) New Pests a Challenge for Area-Wide Programs. Proceedings of Washington State Horticultural Association, 95, 154-158.

[11] Jones, V.P., Eastburn, C.C., Wilburn, E.D. and Brunner, J.F. (2005) Instar-Specific Phenology of Pandemis pyrusana and Choristoneura rosaceana (Lepidoptera: Tortricidae) in Washington Apple Orchards. Journal of Economical Entomology, 98, 875-883. https:/doi.org/10.1603/0022-0493-98.3.875

[12] Brunner, J.F., Gut, L.J. and Knight, A.L. (1994) Transition of Apple and Pear Orchards to a Pheromone-Based Pest Management System. Proceedings of Washington State Horticultural Association, 88, 169-175.

[13] Solymar, B. and Pree, D. (2001) Development of Alternative, IPM-Compatible Strategies for Organophosphate Resistant Obliquebanded Leafroller on Apple. Ontario, 106, 1188911894.

[14] Reissig, W.H., Stanely, B.H. and Hebding, H.E. (1986) Azinphosmethyl Resistance and Weight Related Response of Obliquebanded Leafroller (Lepidoptera: Tortricidae) Larvae to Insecticides. Journal of Economical Entomology, 79, 329-333. https:/doi.org/10.1093/jee/79.2.329

[15] Carriere, Y., Deland, J.P. and Roff, D.A. (1996) Obliquebanded Leafroller (Lepidoptera: Tortricidae) Resistance to Insecticides: Among Orchard Variation and Cross Resistance. Journal of Economical Entomology, 89, 577-582. https:/doi.org/10.1093/jee/89.3.577

[16] Lawson, D.S., Reissig, W.H. and Smith, C.M. (1997) Response of Larval and Adult Obliquebanded Leafroller (Lepidoptera: Tortricidae) to Selected Insecticides. Journal of Economic Entomology, 90, 1450-1457. https:/doi.org/10.1093/jee/90.6.1450

[17] Sauphanor, B., Brosse, V., Monier, C. and Bauvier, J.C. (1998) Differential Ovicidal and Larvicidal Resistance to Benzoylureas in the Codling Moth, Cydia pomonella. Entomologia Experimentalis et Applicata, 88, 247-253. https:/doi.org/10.1046/j.1570-7458.1998.00369.x

[18] Waldstein, D.E., Reissig, W.H., Scott, J.G. and Straub, R.W. (1999) Susceptibility of Obliquebanded Leafroller (Lepidoptera: Tortricidae) Populations from Commercial Orchards and Unsprayed Habitat in New York to Tebufenozide. Journal of Economical Entomology, 92, 1251-1255. https:/doi.org/10.1093/jee/92.6.1251

[19] Ahmad, M., Hollingworth, R.M. and Wise, J.C. (2002) Broad-Spectrum Insecticide Resistance in Obliquebanded Leafroller Choristoneura rosaceana (Lepidoptera: Tortricidae) from Michigan. Pest Management Science, 58, 834-838. https:/doi.org/10.1002/ps.531

[20] Smirle, M.J., Lowery, D.T. and Zurowski, C.L. (2002) Resistance and Cross-Resistance of four Insecticides in Populations of Obliquebanded Leafroller (Lepidoptera: Tortricidae). Journal of Economic Entomology, 95, 820-825. https:/doi.org/10.1603/0022-0493-95.4.820

[21] Dunley, J.E., Brunner, J.F., Doerr, M.D. and Beers, E.H. (2006) Resistance and Cross-Resistance in Populations of Leafrollers, Choristoneura rosaceana and Pandemis pyrusana, in Washington Apples. Journal of Insect Science, 6, 14. https:/doi.org/10.1673/2006_06_14.1

[22] Sial, A.A. and Brunner, J.F. (2010) Assessment of Resistance Risk in Obliquebanded Lea- 
froller (Lepidoptera: Tortricidae) to the Reduced-Risk Insecticides Chlorantraniliprole and Spinetoram. Journal of Economic Entomology, 103, 1378-1385.

https:/doi.org/10.1603/EC09354

[23] Beers, E.H., Martinez-Rocha, L., Talley, R.R. and Dunley, J.E. (2009) Lethal, Sublethal, and Behavioral Effects of Sulfur-Containing Products in Bioassays of Three Species of Orchard Mites. Journal of Economic Entomology, 102, 324-335. https:/doi.org/10.1603/029.102.0143

[24] Thomson, D., Brunner, J., Gut, L., Judd, G. and Knight, A. (2001) Ten Years Implementing Codling Moth Mating Disruption in the Orchards of Washington and British Columbia: Starting Right and Managing for Success! Pheromones for Insect Control in Orchards and Vineyards IOBC-WPRS Bulletin, 24, 23-30.

[25] Brunner, J.F. (2002) New Technologies for Mating Disruption in Tree Fruit Crops. Proceedings of Washington State Horticultural Association, 97, 160-164.

[26] Knight, R.L., Briggs, J.B., Massee, A.M. and Tydeman, H.M. (1962) The Inheritance of Resistance to the Woolly Apple Aphid, Eriosoma lanigerum (Hsmnn.), in the Apple. Journal of Horticultural Science, 37, 207-218. https:/doi.org/10.1080/00221589.1962.11514040

[27] Smith, C.M. and Boyko, E.V. (2006) The Molecular Bases of Plant Resistance and Defense Responses to Aphid Feeding: Current Status. Entomologia Experimentalis et Applicata, 122, 1-16. https:/doi.org/10.1111/j.1570-7458.2006.00503.x

[28] Bus, V.G.M., Chagné, D., Bassett, H.C.M., Bowatte, D., Calenge, F., Celton, J.M., Durel, C.E., Malone, M.T., Patocchi, A., Ranatunga, A.C. and Rikkerink, E.H.A. (2008) Genome Mapping of Three Major Resistance Genes to Woolly Apple Aphid (Eriosoma lanigerum Hausm.). Tree Genetics \& Genomes, 4, 223-236. https:/doi.org/10.1007/s11295-007-0103-3

[29] Bus, V.G., Bassett, H.C., Bowatte, D., Chagné, D., Ranatunga, C.A., Ulluwishewa, D., Wiedow, C. and Gardiner, S.E. (2010) Genome Mapping of an Apple Scab, a Powdery Mildew and a Woolly Apple Aphid Resistance Gene from Open-Pollinated Mildew Immune Selection. Tree Genetics \& Genomes, 6, 477-487. https:/doi.org/10.1007/s11295-009-0265-2

[30] Stoeckli, S., Mody, K. and Dorn, S. (2008) Aphis pomi (Hemiptera: Aphididae) Population Development, Shoot Characteristics, and Antibiosis Resistance in Different Apple Genotypes. Journal of Economic Entomology, 101, 1341-1348. https:/doi.org/10.1603/0022-0493(2008)101[1341:APHAPD]2.0.CO;2

[31] Stoeckli, S., Mody, K., Gessler, C., Patocchi, A., Jermini, M. and Dorn, S. (2008) QTL Analysis for Aphid Resistance and Growth Traits in Apple. Tree Genetics \& Genomes, 4, 833847. https:/doi.org/10.1007/s11295-008-0156-y

[32] Williams, E.B. and Kuc, J. (1969) Resistance in Malus to Venturia Inaequis. Annual Review of Phytopathology, 7, 223-246. https:/doi.org/10.1146/annurev.py.07.090169.001255

[33] Karkussen, T., Krüger, J., Schmidt, H. and Dunemann, F. (1995) Identification of PCRBased Markers Linked to the Powdery-Mildew-Resistance Gene Pl1 from Malus robusta in Cultivated Apple. Plant Breeding, 114, 530-534. https:/doi.org/10.1111/j.1439-0523.1995.tb00850.x

[34] Flachowsky, H., Le Roux, P.M., Peil, A., Patocchi, A., Richter, K. and Hanke, M.V. (2011) Application of a High-Speed Breeding Technology to Apple (Malus $\times$ Domestic) Based on Transgenic Early Flowering Plants and Marker-Assisted Selection. New Phytologist, 192, 364-377. https:/doi.org/10.1111/j.1469-8137.2011.03813.x

[35] Cutright, C.R. and Morrison, H.E. (1965) Varietal Susceptibility in Codling Moth Injury. Journal of Economical Entomology, 28, 107-109. https:/doi.org/10.1093/jee/28.1.107

[36] Pree, D.J. (1977) Resistance to Development of Larvae of the Apple Maggot in Crab Apples. Journal of Economic Entomology, 70, 611-614. https:/doi.org/10.1093/jee/70.5.611

[37] Goonewardene, H.F., Howard, P.H., Oliver, P.J., Pliego, G. and McCabe, G.P. (1989) Con- 
trol of Arthropods on Apple, Malus $\times$ Domestic (Borkh.), Selections for Scab (Ascomycetes: Mycosphaerellace) and Apple Maggot (Diptera: Tephritidae) Resistance in an Orchard in Indiana. Journal of Economical Entomology, 82, 1426-1436.

https:/doi.org/10.1093/jee/82.5.1426

[38] Hunter, M.D., Hull, L.A. and Schultz, J.C. (1994) Evaluation of Resistance to Tufted Apple Bud Moth (Lepidoptera: Tortricidae) within and among Apple Cultivars. Environmental Entomology, 23, 282-291. https:/doi.org/10.1093/ee/23.2.282

[39] Labanowski, G.S. and Sokolowski, R.J. (1996) Effect of the Filbert Leafroller Feeding on Growth and Yield of Apple Trees. Acta Horticulturae, 422, 362-363. https:/doi.org/10.17660/ActaHortic.1996.422.81

[40] Hogmire, H.W. and Miller, S.S. (2005) Relative Susceptibility of New Apple Cultivars to Arthropod Pests. Horticultural Science, 40, 2071-2075.

[41] Płuciennik, Z. and Olszak, R.W. (2005) Feeding Preferences of Leafroller Caterpillars (Lepidoptera, Torticidae) for Some Apple Cultivars. Journal of Plant Protection Research, 45, 293-299.

[42] Onstad, D.W., Reissig, W.H. and Shoemaker, C.A. (1986) Influence of Apple Cultivar, Tree Phenology, and Leaf Quality on the Development and Mortality of Choristoneura rosaceana (Lepidoptera: Tortricidae). Canadian Entomologist, 118, 123-132.

https:/doi.org/10.4039/Ent118123-2

[43] Wearing, C.H., Colhoun, K., McLaren, G.F., Attfield, B. and Bus, V.G.M. (2003) Evidence for Single Gene Resistance in Apple to Brownheaded Leafroller, Ctenopseustis obliquana, and Implications for Resistance to Other New Zealand Leafrollers. Entomologia Experimentalis et Applicata, 108, 1-10. https:/doi.org/10.1046/j.1570-7458.2003.00062.x

[44] Lombarkia, N. and Derridj, S. (2008) Resistance of Apple Trees to Cydia pomonella EggLaying Due to Leaf Surface Metabolites. Entomologia Experimentalis et Applicata, 128, 57 65. https:/doi.org/10.1111/j.1570-7458.2008.00741.x

[45] Stoeckli, S., Mody, K., Gessler, C., Christen, D. and Dorn, S. (2009) Quantitative Trait Locus Mapping of Resistance in Apple to Cydia pomonella and Lyonetia clerkella and of Two Selected Fruit Traits. Annals of Applied Biology, 154, 377-387. https:/doi.org/10.1111/j.1744-7348.2008.00307.x

[46] Stoeckli, S., Mody, K. and Dorn, S. (2008) Influence of Canopy Aspect and Height on Codling Moth (Lepidoptera: Tortricidae) Larval Infestations in Apple, and Relationship between Infestations and Fruit Size. Journal of Economic Entomology, 101, 81-89. https:/doi.org/10.1093/jee/101.1.81

[47] Stoeckli, S., Mody, K., Kellerhals, M. and Dorn, S. (2011) Association between Herbivore Resistance and Fruit Quality in Apple. Horticultural Science, 46, 12-15.

[48] Brunner, J.F. and Doerr, M. (2011) Pest Management Transition: Challenges and Consequences. Compact Fruit Tree, 44, 23-29.

[49] Shorey, H.H. and Hale, R.L. (1965) Mass-Rearing of the Larvae of Nine Noctuid Species on a Simple Artificial Medium. Journal of Economical Entomology, 58, 522-524. https:/doi.org/10.1093/jee/58.3.522

[50] Kenward, M.G. and Roger, J.H. (1997) Small Sample Inference for Fixed Effects from Restricted Maximum Likelihood. Biometrics, 53, 983-997. https:/doi.org/10.2307/2533558

[51] SAS Institute Inc (2011) SAS/STAT ${ }^{\circledast} 9.3$ User’s Guide. SAS Institute Inc., Cary.

[52] Pechan, T., Ye, L., Chang, Y.-M., Mitra, A., Lin, L., Davis, F.M., Williams, W.P. and Luthe, D.S. (2000) A Unique 33-kD Cysteine Proteinase Accumulates in Response to Larval Feeding in Maize Genotypes Resistant to Fall Armyworm and Other Lepidoptera. The Plant Cell, 12, 1031-1040. https:/doi.org/10.1105/tpc.12.7.1031

[53] Pechan, T., Cohen, A., Williams, W.P. and Luthe, D.S. (2002) Insect Feeding Mobilizes a 
Unique Plant Defense Protease That Disrupts the Peritrophic Matrix. Proceedings of the National Academy of Sciences of the United States of America, 99, 13319-13323. https:/doi.org/10.1073/pnas.202224899

[54] Fescemyer, H.W., Sandoya, G.V., Gill, T.A., Ozkan, S., Marden, J.H. and Luthe, D.S. (2013) Maize Toxin Degrades Peritrophic Matrix Proteins and Stimulates Compensatory Transcriptome Responses in Fall Armyworm Midgut. Insect Biochemistry and Molecular Biology, 43, 280-291. https:/doi.org/10.1016/j.ibmb.2012.12.008

[55] Maharijaya, A., Vosman, B., Steenhuis-Broers, G., Harpenas, A., Purwito, A., Visser, R.G. and Voorrips, R.E. (2011) Screening of Pepper Accessions for Resistance against Two Thrips Species (Frankliniella occidentalis and Thrips parvispinus). Euphytica, 177, 401-410. https:/doi.org/10.1007/s10681-010-0277-X

[56] Aqueel, M.A., Collins, C.M., Raza, A-b.M., Shahbaz, A., Tariq, M. and Leather, S.R. (2014) Effect of Plant Nutrition on Aphid Size, Prey Consumption, and Life History Characteristics of Green Lacewing. Insect Science, 21, 74-82. https:/doi.org/10.1111/1744-7917.12019

[57] Marron, M.T., Markow, T.A., Kain, K.J. and Gibbs, A.G. (2003) Effects of starvation and desiccation on energy metabolism in desert and mesic Drosophila. Journal of Insect Physiology, 49, 261-270. https:/doi.org/10.1016/S0022-1910(02)00287-1

[58] Matzkin, L.M. and Markow, T.A. (2009) Transcriptional Regulation of Metabolism Associated with the Increased Desiccation Resistance of the Cactophilic Drosophila mojavensis. Genetics, 182, 1279-1288. https:/doi.org/10.1534/genetics.109.104927

[59] Berger, D. and Gotthard, K. (2008) Time Stress, Predation Risk and Diurnal-Nocturnal Foraging Trade-Offs in Larval Prey. Behavioral Ecology Sociobiology, 62, 1655-1663. https:/doi.org/10.1007/s00265-008-0594-4

[60] Häggström, H. and Larsson, S. (1995) Slow Larvae Growth on a Suboptimal Will Results in High Predation Mortality in the Leaf Beetle Galerucella lineola. Oecologica, 104, 308-315. https:/doi.org/10.1007/BF00328366

[61] Wearing, C.H., Colhoun, K., Attfield, B., Marshall, R.R. and McLaren, G.F. (2003) Screening for Resistance in Apple Cultivars to Lightbrown Apple Moth, Epiphyas postvittana, and Greenheaded Leafroller, Planotortrix octo, and Its Relationship to Field Damage. Entomologia Experimentalis et Applicata, 109, 39-53. https:/doi.org/10.1046/j.1570-7458.2003.00091.x

[62] Tobutt, K.R., Boškovic, R. and Roche, P. (2000) Incompatibility and Resistance to Woolly Apple Aphid in Apple. Plant Breeding, 119, 65-69. https:/doi.org/10.1046/j.1439-0523.2000.00442.x

[63] Alston, F.H., Philipps, K.L. and Evans, K.M. (2000) A Malus Gene List. Acta Horticulturae, 538, 561-570. https:/doi.org/10.17660/ActaHortic.2000.538.98

[64] King, G.J., Alston, F.H., Battle, I., Chevreau, E., Gessler, C., Janse, J., Lindhout, P., Manganaris, A.G., Sansavini, S., Schmidt, H. and Tobutt, K. (1991) The "European Apple Genome Mapping Project": Developing a Strategy for Mapping Genes Coding for Agronomic Characters in Tree Species. Euphytica, 56, 89-94.

[65] Bus, V., Ranatunga, C., Gardiner, S., Bassett, H., Rikkerink, E., Geibel, M., Fischer, M. and Fischer, C. (2000) Marker Assisted Selection for Pest and Disease Resistance in the New Zealand Apple Breeding Programme. Acta Horticulturae, 538, 541-547. https:/doi.org/10.17660/ActaHortic.2000.538.95

[66] Alston, F.H. and Briggs, J.B. (1968) Resistance to Sappaphis devecta (Wlk) in Apple. Euphytica, 17, 468-472. https:/doi.org/10.1007/bf00056249

[67] Alston, F.H. and Briggs, J.B. (1977) Resistance Genes in Apple and Bio-Types of Dysaphis devecta. Annals of Applied Biology, 87, 75-81.

https:/doi.org/10.1111/j.1744-7348.1977.tb00661.x 
[68] Alston, F.H. (1969) Resistance to Collar Rot, Phytophthora cactorurn. (Leb. and Cohn) Schroet., in Apple. Annual Report East Malling Research Station, A53, 143-145.

[69] Hajnajari, H., Damyar, S., Abassi, H. and Moktariyan, A. (2011) Evaluation of Commercial Apple (Malus domestia Borkh.) Cultivars Existing in Divergent Collections of the Country. FAO AGRIS Report.

[70] Gessler, C., Patocchi, A., Sansavini, S., Tartarini, S. and Gianfranceschi, L. (2006) Venturia Inaequalis Resistance in Apple. Critical Reviews in Plant Sciences, 25, 473-503. https:/doi.org/10.1080/07352680601015975

[71] Abe, K., Iwanami, H., Kotoda, N., Moriya, S. and Takahashi Sumiyoshi, S. (2010) Evaluation of Apple Genotypes and Malus Species for Resistance to Alternaria Blotch Caused by Alternaria alternata Apple Pathotype Using Detached-Leaf Method. Plant Breeding, 129, 208-218. https:/doi.org/10.1111/j.1439-0523.2009.01672.x

[72] Miñarro, M. and Dapena, E. (2004) Optimización del control del pulgón ceniciento del manzano con insecticidas derivados del neem. In: Tello, J. Ed., Libro de comunicaciones del VI Congreso de la SEAE, 511-518.

[73] Miñarro, M. and Dapena, E. (2008) Tolerance of Some Scab-Resistant Apple Cultivars to the Rosy Apple Apid, Dysaphis plantaginea. Crop Protection, 27, 391-395. https:/doi.org/10.1016/j.cropro.2007.07.003

[74] Peil, A., Garcia-Libreros, T., Richter, K., Trognitz, F.C., Trognitz, B., Hanke, M.-V. and Flachowsky, H. (2007) Strong Evidence for a Fire Blight Resistance Gene of Malus robusta Located on Linkage Group 3. Plant Breeding, 126, 470-475.

https:/doi.org/10.1111/j.1439-0523.2007.01408.x

[75] Peil, A., Hanke, M.-V., Flachowsky, H., Garcia-Libreros, T., Horner, M., Bus, V., Richter, K., Celton, J.-M. and Gardiner, S. (2008) Confirmation of the Fire Blight QTL of Malus $\times$ Robusta 5 on Linkage Group 3. Acta Horticulturae, 793, 297-303. https:/doi.org/10.17660/ActaHortic.2008.793.44

[76] Khan, M.A., Duffy, B., Gessler, C. and Patocchi, A. (2006) QTL Mapping of Fire Blight Resistance in Apple. Molecular Breeding, 17, 299-306. https:/doi.org/10.1007/s11032-006-9000-y

[77] Khan, M.A., Durel, C.E., Duffy, B., Drouet, D., Kellerhais, M., Gessler, C. and Patocchi, A. (2007) Development of Molecular Markers Linked to the "Fiest" Linkage Group 7 Majore QTL for Fire Blight Resistance and Their Application for Marker-Assisted Selection. $G e-$ nome, 50, 568-577. https:/doi.org/10.1139/G07-033

\section{Submit or recommend next manuscript to SCIRP and we will provide best service for you:}

Accepting pre-submission inquiries through Email, Facebook, LinkedIn, Twitter, etc. A wide selection of journals (inclusive of 9 subjects, more than 200 journals)

Providing 24-hour high-quality service

User-friendly online submission system

Fair and swift peer-review system

Efficient typesetting and proofreading procedure

Display of the result of downloads and visits, as well as the number of cited articles

Maximum dissemination of your research work

Submit your manuscript at: http://papersubmission.scirp.org/

Or contact ae@scirp.org 